\title{
Cryopreservation of 12 Vitis Species Using Apical Shoot Tips Derived from Plants Grown In Vitro
}

\author{
Jean Carlos Bettoni ${ }^{1}$ and Aike Anneliese Kretzschmar \\ Santa Catarina State University (UDESC), Lages, Santa Catarina, \\ 88520000, Brazil
}

\author{
Remi Bonnart, Ashley Shepherd, and Gayle M. Volk ${ }^{1}$ \\ USDA-ARS National Laboratory for Genetic Resources Preservation, 1111 \\ S. Mason Street, Fort Collins, CO 80521
}

\section{Additional index words. genebank, grapevine, plant vitrification solution}

\begin{abstract}
The availability of and easy access to diverse Vitis species are prerequisites for advances in breeding programs. Plant genebanks usually maintain collections of Vitis taxa as field collections that are vulnerable to biotic and abiotic stresses. Cryopreservation has been considered an ideal method of preserving these collections as safety backups in a cost-effective manner. We report a droplet vitrification method used to cryopreserve 12 Vitis species (Vitis vinifera cvs. Chardonnay and 'Riesling, $V$. actinifolia, $V$. aestivalis, $V$. jacquemontii, $V$. flexuosa, $V$. palmata, $V$. riparia, $V$. rupestris, $V$. sylvestris, $V$. ficifolia, $V$. treleasi, and $V$. $\times$ novae angeliae) using shoot tips excised from plants grown in vitro. Our results demonstrated wide applicability of this technique, with regrowth levels at least $43 \%$ for 13 genotypes representing 12 Vitis species. We demonstrated that the droplet vitrification procedure can be successfully replicated by technical staff, thus suggesting that this method is ready for implementation.
\end{abstract}

Grape (Vitis spp.) is one of the most economically important fruit crops cultivated and consumed worldwide (OIV, 2018). Vitis has a rich genetic diversity; there are more than 70 species within the genus, with most of the globally important cultivars assigned to Vitis vinifera (Li et al., 2017). Wild Vitis species as well as Muscadinia rotundifolia have been used for hybrid grape breeding as new cultivars and rootstocks, many of which provide resistance to pests and diseases (Carimi et al., 2011; Eibach et al., 2007; Smith et al., 2017).

The availability of and easy access to Vitis genetic resources are essential for breeding programs (Carimi et al., 2016). Vitis genebank

Received for publication 11 Feb. 2019. Accepted for publication 19 Mar. 2019

This work was supported in part by the USDA-ARS National Laboratory for Genetic Resources Preservation) and The Science and Technology Development Fund (STDF/Egypt).

The authors are grateful to the Coordination for the Improvement of Higher Education Personnel (CAPES) of the Brazilian Ministry of Education (MEC) for the PhD Scholarship in Brazil and the Scholarship for the $\mathrm{PhD}$ Sandwich Program Abroad (PDSE) in the United States of America granted to Jean Carlos Bettoni to perform research at the USDA-ARS National Laboratory for Genetic Resources Preservation (NLGRP). Research was funded in part by NAS and USAID, and any opinions, findings, conclusions, or recommendations expressed are those of the authors alone and do not necessarily reflect the views of USAID or NAS. The authors thank Ben Gutierrez for providing an internal review of the manuscript.

${ }^{1}$ Corresponding author. E-mail: gayle.volk@ars.usda. gov. collections are traditionally conserved in field repositories. Field maintenance is costly and time-consuming, it requires extensive acreage, and plants are vulnerable to abiotic stresses and biotic threats (Benelli et al., 2013; Marković et al., 2013b; Pathirana et al., 2016). In vitro culture back-up is one alternative to short-term preservation of Vitis germplasm (Hassan et al., 2013; Postman et al., 2006), but it has some limitations because tissue culture is labor-intensive and cultures could become contaminated or undergo somaclonal variation (Kaya and Souza, 2017; Mathew et al., 2018; Souza et al., 2016).

Cryopreservation is the storage of biological materials in liquid nitrogen (LN) $\left(-196{ }^{\circ} \mathrm{C}\right)$ or $\mathrm{LN}$ vapor $\left(-165\right.$ to $\left.-190{ }^{\circ} \mathrm{C}\right)$. Cryopreservation methods have been used to securely conserve portions of plant genebank collections for long durations. Under cryopreservation conditions, viable propagules are preserved in a state in which cellular divisions and metabolic processes are minimized (Benelli et al., 2013; Wang et al., 2018). Compared with the cost of creating duplicated field collections, it is costeffective to establish cryopreserved back-up collections (Benson, 2008).

Although there are many established cryobanks that conserve vegetative propagules such as shoot tips or dormant buds of clonally propagated genetic resources (Towill et al., 2004; Wang et al., 2014), to the best of our knowledge, Vitis cryo-storage has not been fully implemented within genebanks. Limited results were obtained when Vitis dormant buds were cryopreserved (Esensee and Stushnoff, 1990). Results have been more promising for
Vitis shoot tip cryopreservation. Several works have reported successful shoot tip cryopreservation (Bi et al., 2017; Hassan and Haggag, 2013; Pathirana et al., 2016). However, genotype-specific responses have made these procedures difficult to implement (Benelli et al., 2003; Ganino et al., 2012; Pathirana et al., 2016). Most Vitis cryopreservation research has focused on the development of procedures using a limited number of species (Bi et al., 2017). So far, the droplet vitrification technique appears to be a promising method to overcome species-specific and genotypespecific responses to Vitis cryopreservation (Bi et al., 2018a; Volk et al., 2018). Droplet vitrification uses ultra-fast shoot tip cooling and warming conditions, which are an important requirement for successful cryopreservation protocols based on vitrification (Benson and Harding, 2012; Kaya et al., 2013; Souza et al., 2016).

Access to reliable cryopreservation methods that result in high levels of viability ( $\geq 40 \%$ after LN exposure) and highly skilled staff are crucial to the development of successful base collections (Volk et al., 2016). We describe the development of a widely applicable droplet vitrification procedure to cryopreserve Vitis shoot tips from in vitro stock plants.

\section{Materials and Methods}

Plant materials and pretreatments. All plant materials were originally received from the USDA-ARS National Clonal Germplasm Repository for Tree Fruit, Nut Crops, and Grapes in Davis, CA, and introduced from the field to in vitro conditions. Young shoot tissue was washed with soapy water, rinsed, and treated with $70 \%$ isopropanol for $1 \mathrm{~min}$, followed by two rinses with distilled water and treatment with $10 \%$ bleach $(8.25 \%$ sodium hypochlorite) and $0.1 \%$ Tween $20(\mathrm{v} / \mathrm{v})$ for $10 \mathrm{~min}$. Then, the tissue was rinsed three times in sterile distilled water. Vitis accessions included Vitis vinifera cvs. Chardonnay and Riesling, V. actinifolia (DVIT 2594.1), $V$. aestivalis (DVIT 1408), V. jacquemontii (PI 135726), $V$. flexuosa (DVIT 1385), $V$. palmata (DVIT 2228.1), V. riparia (PI 588214), V. rupestris (DVIT 8166), V. sylvestris (DVIT 2426.1), V. ficifolia (DVIT 2008.1), V. treleasi (DVIT 1410) and $V$. ×novae angeliae (DVIT 1457).

Stock cultures were maintained and subcultured every 8 to 12 weeks in glass culture vessels $(89 \times 170 \mathrm{~mm})$ on MS medium (Murashige and Skoog, 1962) containing $30 \mathrm{~g} \cdot \mathrm{L}^{-1}$ sucrose, $0.175 \mathrm{mg} \cdot \mathrm{L}^{-1}$ indole-3acetic acid (IAA), and $2.5 \mathrm{~g} \cdot \mathrm{L}^{-1}$ gellan gum at $\mathrm{pH} 5.7$ (pH 6.4 before autoclaving). Cultures were grown at $25^{\circ} \mathrm{C}$ during a photoperiod of $16 \mathrm{~h}$ of daylight with light intensity of $40 \mu \mathrm{M} \cdot \mathrm{m}^{-2} \cdot \mathrm{s}^{-1}$.

Nodal sections were obtained from 2- to 3 -month-old in vitro stock plants and placed in $100-\times 25-\mathrm{mm}$ plastic petri dishes with $50 \mathrm{~mL}$ pretreatment medium [MS salts/vitamins supplemented with $30 \mathrm{~g} \cdot \mathrm{L}^{-1}$ sucrose, $0.2 \mathrm{mg} \cdot \mathrm{L}^{-1}$ 6-benzyl aminopurine (BA), $0.1 \mathrm{~mm}$ salicylic 
acid, $1 \mathrm{~mm}$ ascorbic acid, $1 \mathrm{~mm}$ glutathione (reduced form), and $3 \mathrm{~g} \cdot \mathrm{L}^{-1}$ gellan gum at $\mathrm{pH}$ $5.7(\mathrm{pH} 6.4$ before autoclaving)] with a density of 40 nodal sections $(1-2 \mathrm{~cm})$ per plate and cultured for 2 weeks under the same conditions as the in vitro stock cultures. This step provided uniform apical shoot tips for cryopreservation experiments that were the same as those described for $V$. vinifera $\mathrm{cv}$. Portland by Marković et al. (2014). Next, nodal sections were cold-acclimated at $5{ }^{\circ} \mathrm{C}$ during a 16-h photoperiod for an additional 2 weeks (when applied).

Preculture and cryopreservation. Uniform apical shoot tips (1-mm length, 1-mm width) were excised from nodal sections that either had or had not been cold-acclimated. Shoot tips were cultured on preculture medium [half-strength MS medium containing $0.3 \mathrm{M}$ sucrose, $0.1 \mathrm{~mm}$ salicylic acid, $1 \mathrm{~mm}$ ascorbic acid, $1 \mathrm{~mm}$ glutathione (reduced form), and $3 \mathrm{~g} \cdot \mathrm{L}^{-1}$ gellan gum at $\mathrm{pH} 5.7(\mathrm{pH}$ 6.94 before autoclaving)] for $3 \mathrm{~d}$ at $25^{\circ} \mathrm{C}$ in darkness. Then, they were placed in loading solution [half-strength MS, $2 \mathrm{M}$ glycerol, $0.4 \mathrm{M}$ sucrose, $\mathrm{pH} 5.7$ ( $\mathrm{pH} 6.9$ before autoclaving)] for $20 \mathrm{~min}$ at $22{ }^{\circ} \mathrm{C}$, followed by half-strength PVS2 [filter-sterilized halfstrength MS, $0.4 \mathrm{M}$ sucrose, $15 \%(\mathrm{w} / \mathrm{v})$ glycerol, 7.5\% (w/v) ethylene glycol (EG), $7.5 \%(\mathrm{w} / \mathrm{v})$ dimethyl sulfoxide (DMSO), $\mathrm{pH}$ 5.8] (Matsumoto and Sakai, 2003) for $30 \mathrm{~min}$ at $22{ }^{\circ} \mathrm{C}$ and full-strength PVS2 [filter-sterilized half-strength MS, $0.4 \mathrm{M}$ sucrose, $30 \%(\mathrm{w} / \mathrm{v})$ glycerol, $15 \%(\mathrm{w} / \mathrm{v})$ EG, $15 \%(\mathrm{w} / \mathrm{v})$ DMSO, pH 5.8] (Sakai et al., 1990) at $0{ }^{\circ} \mathrm{C}$ for $60,75,90$, or 105 min. Two minutes before the end of each treatment, PVS2-treated shoot tips were placed on a thin layer of PVS2 on sterile aluminum foil strips $(\approx 6 \times 25 \mathrm{~mm})$ and then plunged in LN.
Regrowth after cryo-exposure. After 1 hour of LN exposure (Mandal and DixitSharma, 2007; Yi et al., 2018), the aluminum foil strips with shoot tips were warmed quickly by inverting the strips in unloading solution [half-strength MS, $1.2 \mathrm{M}$ sucrose, $\mathrm{pH} 5.7$ (pH 7.5 before autoclaving)] at $22^{\circ} \mathrm{C}$ and diluted for $20 \mathrm{~min}$.

For recovery, shoot tips were placed on recovery medium 1 [half-strength MS macroelements without ammonium, full-strength MS microelements, and Vitis vitamins (100 mg. $\mathrm{L}^{-1}$ myo inositol, $10 \mathrm{mg} \cdot \mathrm{L}^{-1}$ thiamine $\mathrm{HCl}, 1 \mathrm{mg} \cdot \mathrm{L}^{-1}$ nicotinic acid, $1 \mathrm{mg} \cdot \mathrm{L}^{-1}$ pyridoxine $\mathrm{HCl}, 1 \mathrm{mg} \cdot \mathrm{L}^{-1} \mathrm{Ca}$ pantothenate, $0.01 \mathrm{mg} \cdot \mathrm{L}^{-1}$ biotin, $2 \mathrm{mg} \cdot \mathrm{L}^{-1}$ glycine) supplemented with $0.6 \mathrm{M}$ sucrose and $8 \mathrm{~g} \cdot \mathrm{L}^{-1}$ agar at $\mathrm{pH} 5.7$ (pH 7.0 before autoclaving) overnight in the dark. They were transferred to recovery medium 2 (half-strength MS macroelements without ammonium and full-strength MS microelements with Vitis vitamins) supplemented with $30 \mathrm{~g} \cdot \mathrm{L}^{-1}$ sucrose, $0.2 \mathrm{mg} \cdot \mathrm{L}^{-1}$ $\mathrm{BA}^{3}$, and $8 \mathrm{~g} \cdot \mathrm{L}^{-1}$ agar at $\mathrm{pH} 5.7(\mathrm{pH} 6.5$ before autoclaving) and cultured for 2 weeks at $25{ }^{\circ} \mathrm{C}$ in darkness. They were then transferred to recovery medium 3 (half-strength MS macroelements and full-strength MS microelements with Vitis vitamins) supplemented with $30 \mathrm{~g} \cdot \mathrm{L}^{-1}$ sucrose, $0.2 \mathrm{mg} \cdot \mathrm{L}^{-1}$ $\mathrm{BA}^{3}$, and $8 \mathrm{~g} \cdot \mathrm{L}^{-1}$ agar at $\mathrm{pH} 5.7(\mathrm{pH} 6.5$ before autoclaving) and grown in the light at $25^{\circ} \mathrm{C}\left(40 \mu \mathrm{M} \cdot \mathrm{m}^{-2} \cdot \mathrm{s}^{-1}, 16-\mathrm{h}\right.$ photoperiod $)$.

Application of cryopreservation to additional Vitis species. The applicability of the droplet vitrification protocol was evaluated for in vitro source plants of five additional Vitis species: $V$. vinifera cv. Riesling, $V$. actinifolia (DVIT 2594.1), $V$. ficifolia (DVIT 2008.1), V. treleasi (DVIT 1410), and $V$. $\times$ novae angeliae (DVIT 1457). This experiment was performed as described, except that shoot tips were exposed to PVS2 for 90 min at $0{ }^{\circ} \mathrm{C}$.

Cryopreservation by a second technical expert. The first series of experiments with eight Vitis species was performed by a single technical expert to identify optimum PVS2 exposure durations and the effect of cold acclimation on shoot tip regrowth after cryo-exposure. The optimized method with 90 min of full-strength PVS2 exposure was tested with five additional Vitis accessions. Cryopreservation experiments were then performed by a second technical expert using four of the same five additional accessions to determine the extent to which the method could be successfully performed by others

Regrowth and data analyses. Shoot tip regrowth (organized shoots with at least one leaf) was measured 8 weeks after plating on regrowth medium. Each experiment was performed with two replicates of 20 shoot tips for each treatment. Means and SE were calculated across experimental replicates and analyzed using analysis of variance, and means separation tests were performed using Tukey's mean separation test. $P \leq 0.05$ was considered significantly different.

\section{Results}

Regrowth of cryopreserved Vitis shoot tips. Across the species evaluated by the first technical expert ( $V$. vinifera 'Chardonnay', $V$. aestivalis, $V$. jacquemontii, $V$. flexuosa, $V$. palmata, $V$. riparia, $V$. rupestris, and $V$. sylvestris), shoot tips that were not exposed to $\mathrm{LN}(-\mathrm{LN})$ and not cold-acclimated had higher average regrowth levels with 60,75 , 90 , and 105 min of PVS2 exposure $(63 \%$ to $71 \%$ ) compared with the corresponding LN treatment $(+\mathrm{LN})(37 \%$ to $53 \%)$ (Table 1$)$. Similarly, shoot tips that were not exposed to

Table 1. Regrowth level (\%) of shoot tips excised from nodal sections sourced from eight Vitis species grown in vitro with $60,75,90$ and 105 min of plant vitrification solution 2 (PVS2) exposure with and without liquid nitrogen (LN) exposure and without cold acclimation. ${ }^{2}$

$-\mathrm{LN}$

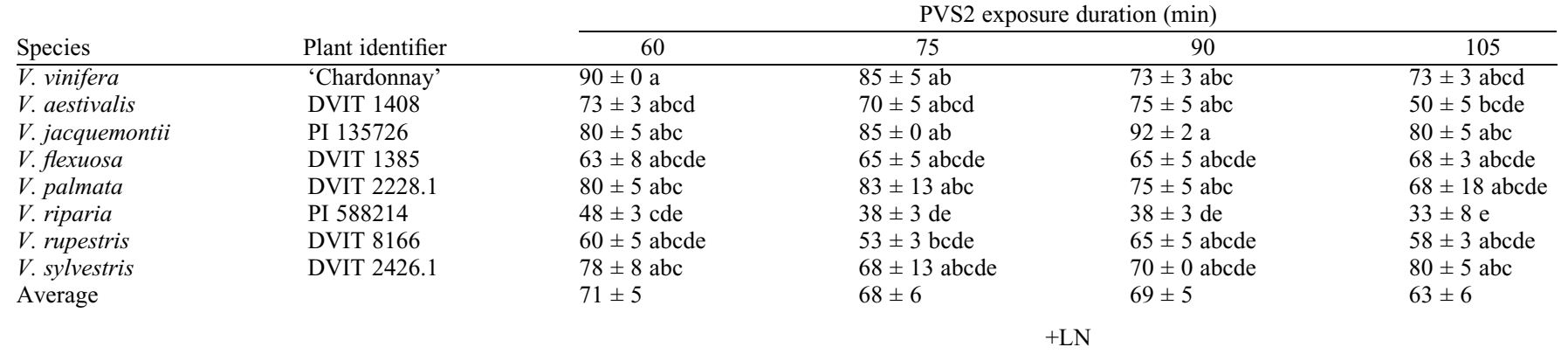

\begin{tabular}{|c|c|c|c|c|c|}
\hline Species & Plant identifier & \multicolumn{4}{|c|}{ PVS2 exposure duration (min) } \\
\hline V. aestivalis & DVIT 1408 & $38 \pm 3$ defgh & $58 \pm 3$ abcd & $58 \pm 3 \mathrm{abcd}$ & $33 \pm 8$ efgh \\
\hline$V$. jacquemontii & PI 135726 & $48 \pm 3$ abcdefg & $50 \pm 5$ abcdef & $72 \pm 2 \mathrm{a}$ & $53 \pm 8$ abcde \\
\hline V. palmata & DVIT 2228.1 & $30 \pm 5$ efgh & $53 \pm 3$ abcde & $53 \pm 3$ abcd & $45 \pm 5$ bcdefgh \\
\hline V. riparia & PI 588214 & $23 \pm 3 \mathrm{~h}$ & $28 \pm 3 \mathrm{fgh}$ & $35 \pm 5$ defgh & $25 \pm 5 \mathrm{gh}$ \\
\hline V. rupestris & DVIT 8166 & $38 \pm 8$ defgh & $43 \pm 8$ cdefgh & $43 \pm 8$ cdefgh & $33 \pm 3$ efgh \\
\hline
\end{tabular}

${ }_{\mathrm{z}}$ Data represent mean \pm SE. Values followed by different letters within the set of $-\mathrm{LN} / \mathrm{PVS} 2$ exposure combinations and within the set of $+\mathrm{LN} / \mathrm{PVS} 2$ exposure combinations were significantly different at $P<0.05$ using Tukey's mean separation test. 
LN and were cold-acclimated had higher levels of regrowth with $60,75,90$, and 105 min of PVS2 exposure (58\% to $72 \%$ ) compared with the corresponding LN treatment ( $+\mathrm{LN})(39 \%$ to $59 \%)$ (Table 2$)$. There were no differences in the regrowth levels of - LN shoot tips that were cold-acclimated at $5{ }^{\circ} \mathrm{C}$ for 2 weeks and those that were not cold-acclimated for the corresponding PVS2 exposure durations.

The shoot tips that were not coldacclimated and had the lowest regrowth levels $(-\mathrm{LN})$ were $V$. riparia with $60 \mathrm{~min}$ of PVS2 (48\%), V. riparia (38\%) and $V$. rupestris $(53 \%)$ with 75 min of PVS2, $V$. riparia with 90 min of PVS2 (38\%), and $V$. aestivalis $(50 \%)$ and $V$. riparia $(33 \%)$ with $105 \mathrm{~min}$ of PVS2 exposure (Table 1, Fig. 1). Similarly, with cold acclimation, the lowest regrowth levels (-LN) were obtained for $V$. riparia ( $48 \%$ after $60 \mathrm{~min}$ of PVS2 and 53\% after 75 min of PVS2), $V$. jacquemontii (55\% after $90 \mathrm{~min}$ of PVS2), $V$. riparia (43\% after 90 min of PVS2), $V$. aestivalis (48\% after $105 \mathrm{~min}$ of PVS2), $V$. jacquemontii (58\% after $105 \mathrm{~min}$ of PVS2), $V$. riparia ( $38 \%$ after $105 \mathrm{~min}$ of PVS2), $V$. rupestris (53\% after $105 \mathrm{~min}$ of PVS2), and V. sylvestris ( $50 \%$ after $105 \mathrm{~min}$ of PVS2) (Table 2). Overall, the $V$. riparia accession responded less positively to the PVS2 treatment than did the other species.

The highest regrowth levels with LN were obtained after $90 \mathrm{~min}$ of PVS2 exposure and no cold acclimation: $V$. vinifera 'Chardonnay', 58\%; V. aestivalis, 58\%; V. jacquemontii, 72\%; V. flexuosa, 48\%; V. palmata, 53\%; $V$. riparia, $35 \%$; V. rupestris, $43 \%$; and $V$. sylvestris, $63 \%$ (Table 1, Fig. 1). The highest regrowth levels with $\mathrm{LN}$ were obtained after 75 min of PVS2 with cold acclimation:
V. vinifera 'Chardonnay', 70\%; V. aestivalis, $58 \%$; V. jacquemontii, 58\%; V. flexuosa, $65 \%$; V. palmata, $60 \%$; V. riparia, $43 \%$; $V$. rupestris, $55 \%$; and $V$. sylvestris, $68 \%$ (Table 2). In general, shoot tips excised from cold-acclimated plants needed less PVS2 exposure than shoot tips that were not coldacclimated. With 90 min of $+\mathrm{LN}$ treatment without cold acclimation, seven of the eight species met our goal of $40 \%$ regrowth (Table 1). With $75 \mathrm{~min}$ of $+\mathrm{LN}$ treatment with cold acclimation, all eight species met our goal of $40 \%$ regrowth (Table 2 ).

Application of the procedure to additional Vitis species. The droplet vitrification procedure with no cold acclimation and $90 \mathrm{~min}$ of full-strength PVS2 was tested using five additional genotypes ( $V$. actinifolia, $V$. ficifolia, $V$. treleasi, $V$. vinifera 'Riesling', and $V$. $\times$ novae angeliae) to determine its applicability to additional species. During the control treatment $(-\mathrm{LN})$, shoot tips exposed to full-strength PVS2 for $90 \mathrm{~min}$ had an average regrowth level of $82 \%$. The corresponding cryo-exposed $(+\mathrm{LN})$ shoot tip regrowth levels ranged from $43 \%$ for $V$. treleasi to $68 \%$ for $V$. vinifera 'Riesling'. Across the five Vitis genotypes, the average level of regrowth was $57 \%$ (Table 3 ).

Replication of the method by a second technical expert. A second technical expert assessed the regrowth levels of shoot tips of $V$. actinifolia, $V$. ficifolia, $V$. treleasii, $V$. vinifera 'Riesling', and $V$. ×novae angeliae that were excised from nodal sections either with or without cold acclimation, exposed to full-strength PVS2 for 60,75 , or $90 \mathrm{~min}$, and either exposed to $\mathrm{LN}(+\mathrm{LN})$ or not exposed to LN (-LN) (Tables 4 and 5).

Average regrowth levels of the noncoldacclimated and non-LN-treated shoot tips of $V$. actinifolia, $V$. treleasii, $V$. vinifera 'Riesling', and $V$. Xnovae angeliae were $74 \%$ for $60 \mathrm{~min}$ of PVS2, $65 \%$ for $75 \mathrm{~min}$ of PVS2, and $64 \%$ for $90 \mathrm{~min}$ of PVS2 exposure (Table 4). With LN exposure and no cold acclimation, average shoot tip regrowth levels were $54 \%$ for $60 \mathrm{~min}$ of PVS2, 49\% for $75 \mathrm{~min}$ of PVS2, and $48 \%$ for 90 min of PVS2 exposure (Table 4). For noncold-acclimated shoot tips, there were no statistically significant differences among accessions with respect to regrowth levels and PVS2 treatments (Table 4).

For shoot tips that were cold-acclimated and did not undergo LN treatment, the average regrowth levels were $76 \%, 72 \%$, and $71 \%$ for 60,75 , and $90 \mathrm{~min}$ of PVS2 exposure, respectively (Table 5). There were significant differences among accessions with respect to regrowth levels of coldacclimated shoot tips after LN exposure (Table 5). With cold acclimation and LN exposure, $V$. actinifolia ( $85 \%$ regrowth) and $V$. vinifera $\mathrm{cv}$. Riesling (73\% regrowth) had the highest regrowth levels and V. ficifolia had the lowest regrowth levels (38\%) after 75 min of PVS2 exposure (Table 5).

Both technical experts achieved average regrowth levels greater than the threshold level of $40 \%$ (Volk et al., 2016) for the $V$. actinifolia, $V$. treleasii, $V$. vinifera 'Riesling', and $V . \times$ novae angeliae shoot tips that were exposed to full-strength PVS2 for $90 \mathrm{~min}$ without cold acclimation and then cryopreserved (Tables 3 and 4).

\section{Discussion}

Cryopreservation is a reliable and costeffective method for the long-term storage of vegetatively propagated plant germplasm

Table 2. Regrowth level (\%) of shoot tips excised from nodal sections sourced from eight Vitis species grown in vitro with 60, 75, 90, and 105 min of plant vitrification solution 2 (PVS2) exposure with and without liquid nitrogen (LN) exposure and 2 weeks of cold acclimation. ${ }^{2}$

\begin{tabular}{|c|c|c|c|c|c|}
\hline \multirow[b]{3}{*}{ Species } & \multirow[b]{3}{*}{ Plant identifier } & \multicolumn{4}{|c|}{$-\mathrm{LN}$} \\
\hline & & \multicolumn{4}{|c|}{ PVS2 exposure duration (min) } \\
\hline & & 60 & 75 & 90 & 105 \\
\hline V. vinifera & 'Chardonnay' & $85 \pm 0 \mathrm{ab}$ & $85 \pm 0 \mathrm{Ab}$ & $83 \pm 3 a b c$ & $83 \pm 8$ abc \\
\hline$V$. aestivalis & DVIT 1408 & $60 \pm 0$ abcdefgh & $72 \pm 3$ abcdef & $63 \pm 3$ abcdefgh & $48 \pm 3 \mathrm{fgh}$ \\
\hline$V$. jacquemontii & PI 135726 & $78 \pm 3$ abcde & $68 \pm 3$ abcdefg & $55 \pm 15$ cdefgh & $58 \pm 8$ bcdefgh \\
\hline V. flexuosa & DVIT 1385 & $88 \pm 3 \mathrm{a}$ & $85 \pm 5 \mathrm{Ab}$ & $75 \pm 5$ abcdef & $80 \pm 0$ abcd \\
\hline V. palmata & DVIT 2228.1 & $75 \pm 5$ abcdef & $68 \pm 8$ abcdefg & $68 \pm 13$ abcdefg & $60 \pm 0$ abcdefgh \\
\hline$V$. riparia & PI 588214 & $48 \pm 3 \mathrm{fgh}$ & $53 \pm 3$ defgh & $43 \pm 3 \mathrm{gh}$ & $38 \pm 3 \mathrm{~h}$ \\
\hline$V$. rupestris & DVIT 8166 & $70 \pm 5$ abcdefg & $60 \pm 0$ abcdefgh & $70 \pm 5$ abcdefg & $53 \pm 3$ defgh \\
\hline$V$. sylvestris & DVIT 2426.1 & $70 \pm 5$ abcdefg & $68 \pm 3$ abcdefg & $73 \pm 8$ abcdef & $50 \pm 0$ efgh \\
\hline \multirow[t]{3}{*}{ Average } & & $72 \pm 5$ & $70 \pm 4$ & $66 \pm 4$ & $58 \pm 6$ \\
\hline & & \multicolumn{4}{|c|}{$+\mathrm{LN}$} \\
\hline & & \multicolumn{4}{|c|}{ PVS2 exposure duration (min) } \\
\hline Species & Plant identifier & 60 & 75 & 90 & 105 \\
\hline$V$. vinifera & 'Chardonnay' & $58 \pm 3$ abcde & $70 \pm 0 \mathrm{a}$ & $58 \pm 8$ abcde & $45 \pm 0$ abcdefg \\
\hline$V$. aestivalis & DVIT 1408 & $48 \pm 3$ abcdefg & $58 \pm 3$ abcde & $40 \pm 5$ cdefg & $28 \pm 8 \mathrm{~g}$ \\
\hline$V$. jacquemontii & PI 135726 & $55 \pm 5$ abcdef & $58 \pm 3$ abcde & $53 \pm 3$ abcdefg & $38 \pm 3$ defg \\
\hline V.flexuosa & DVIT 1385 & $55 \pm 5$ abcdef & $65 \pm 5 \mathrm{abc}$ & $53 \pm 3 \mathrm{abcd}$ & $55 \pm 10$ abcdef \\
\hline V. palmata & DVIT 2228.1 & $55 \pm 5$ abcdef & $60 \pm 0$ abcd & $58 \pm 3$ abcdefg & $30 \pm 5 \mathrm{fg}$ \\
\hline$V$. riparia & PI 588214 & $33 \pm 3 \mathrm{efg}$ & $43 \pm 3$ bcdefg & $33 \pm 3$ efg & $28 \pm 3 \mathrm{~g}$ \\
\hline$V$. rupestris & DVIT 8166 & $45 \pm 0$ abcdefg & $55 \pm 5$ abcdef & $58 \pm 8$ abcde & $40 \pm 5$ cdefg \\
\hline V. sylvestris & DVIT 2426.1 & $55 \pm 5$ abcdef & $68 \pm 3 \mathrm{ab}$ & $58 \pm 8$ abcde & $48 \pm 3$ abcdefg \\
\hline Average & & $50 \pm 3$ & $59 \pm 3$ & $51 \pm 3$ & $39 \pm 4$ \\
\hline
\end{tabular}

combinations are significantly different at $P<0.05$ using Tukey's mean separation test. 


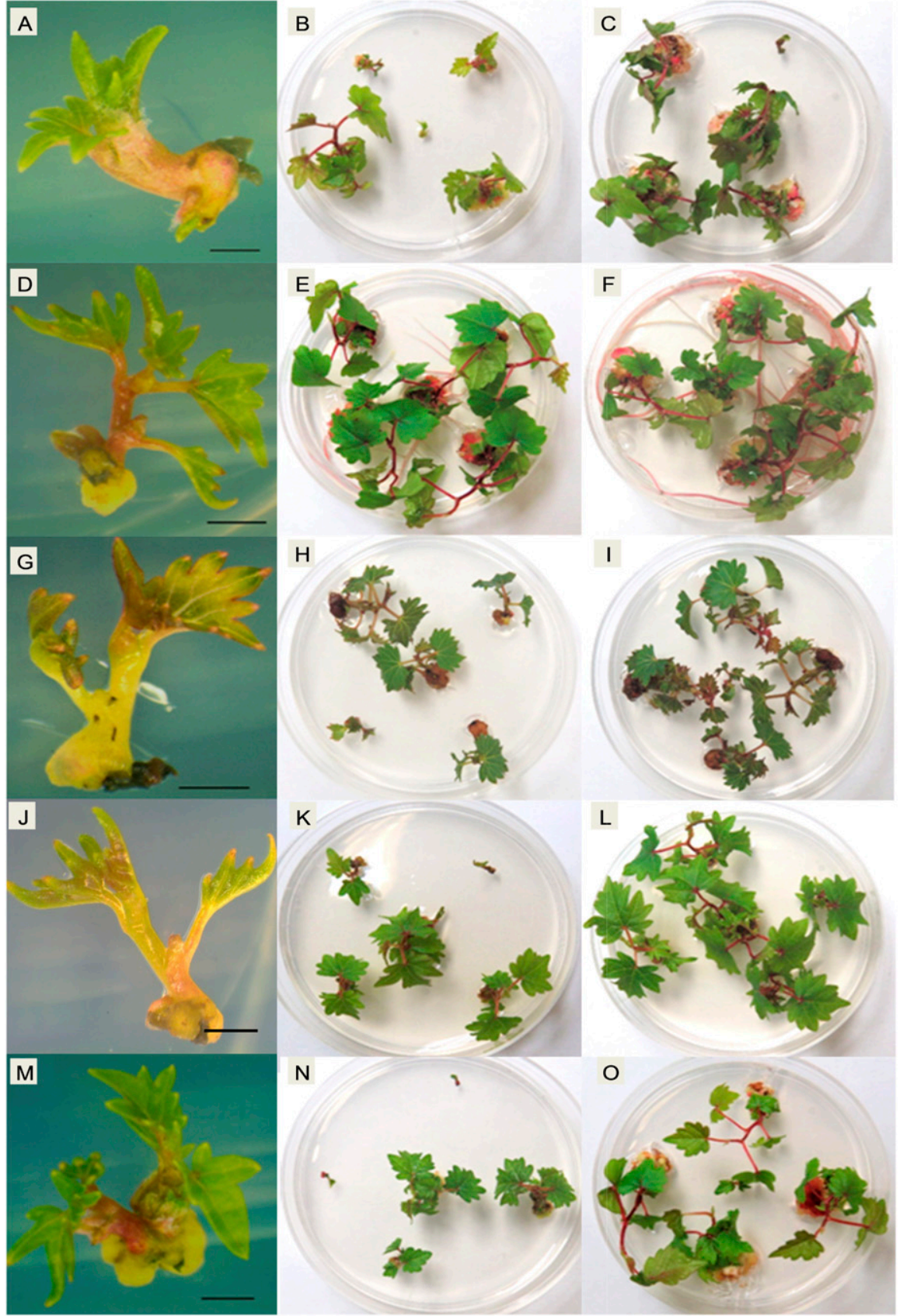

Fig. 1. Grapevine plants recovered after 90 min of plant vitrification solution 2 (PVS2) treatment with liquid nitrogen $(+\mathrm{LN})$ or without liquid nitrogen $(-\mathrm{LN})$ exposure. $V$. aestivalis shoot tips exposed to $\mathrm{LN}$ and recovered for $30 \mathrm{~d}(\mathbf{A})$ and 2 months (B) and without LN exposure after 2 months of regrowth (C). $V$. jacquemontii shoot tips exposed to $\mathrm{LN}$ and recovered for $30 \mathrm{~d}(\mathbf{D})$ and 2 months $(\mathbf{E})$ and without $\mathrm{LN}$ exposure after 2 months of regrowth (F). 'Chardonnay' shoot tips exposed to LN and recovered for $30 \mathrm{~d}$ (G) and 2 months $(\mathbf{H})$ and without $\mathrm{LN}$ exposure after 2 months of regrowth (I). $V$. flexuosa shoot tips exposed to $\mathrm{LN}$ and recovered for $30 \mathrm{~d}(\mathbf{J})$ and 2 months $(\mathbf{K})$ and without $\mathrm{LN}$ exposure after 2 months of regrowth (L). V. palmata shoot tips exposed to $L N$ and recovered for $42 \mathrm{~d}(\mathbf{M})$ and 2 months $(\mathbf{N})$ and without $\mathrm{LN}$ exposure after 2 months of regrowth $(\mathbf{O})$. Scale bars: $\mathbf{A}=1 \mathrm{~mm} ; \mathbf{D}, \mathbf{G}, \mathbf{J}, \mathbf{M}=2 \mathrm{~mm}$.

because when collections are established in $\mathrm{LN}$, cryopreserved collections require minimal space, labor, and maintenance (Benelli et al., 2013; Wang et al., 2018). Our droplet vitrification technique was effective for the cryopreservation of Vitis species using apical shoot tips from in vitro plants. This method resulted in regrowth levels of at least $43 \%$ for 13 genotypes representing 12 Vitis species, including two $V$. vinifera cultivars. et al., 2015, 2016; Marković et al., 2013a, 2013b, 2014; Volk et al., 2018; Bettoni et al., 2019a), and V cryo-plate (Bettoni et al., 2019b) methods. For Vitis, previous reports focused on developing and applying methods primarily to $V$. vinifera cultivars, and it has been difficult to extend these procedures to the diverse range of Vitis species conserved within plant genebanks (Bi et al., 2017). Our goal was to identify a protocol that effectively cryopreserved diverse Vitis species to help eliminate the genotype-specific responses that limit the application of Vitis cryopreservation in genebanks.

Vitis cryopreservation protocols have been established using apical and axillary shoot tips excised directly from 3-week-old to 5-month-old in vitro stock plants (Benelli et al., 2003; Matsumoto and Sakai, 2003; Wang et al., 2000) or axillary shoot tips excised directly from 1-year-old greenhouse plants (Hassan and Haggag, 2013). In a recent study, Pathirana et al. (2016) found that shoot tips located at different positions along the shoot have differing regrowth responses to PVS2 exposure. The quality and physiological state of the stock cultures were thought to be key factors in successful Vitis cryopreservation (Bi et al., 2017; Marković et al., 2014). Our protocol used in vitro plants as source materials. Nodal sections from in vitro plants were placed on shooting medium for 2 weeks to generate shoots from which uniform 1-mm apical shoot tips could be excised. Previously, Marković et al. (2014) observed that shoot tips sampled from microcuttings had higher regrowth compared with shoot tips sampled directly from in vitro stock plants.

Successful cryopreservation procedures are dependent on having optimized pretreatment conditions (Volk et al., 2018). Pretreatments can differ by species and may include cold treatment exposure (Mathew et al., 2018), adding osmotic agents such as sorbitol and sugars, antioxidants such as glutathione reductase and ascorbic acid (Mathew et al., 2018; Reed, 2014; Volk et al., 2018), and elicitors of defense-related proteins in plants such as salicylic acid (Pathirana et al., 2016; Volk et al., 2018). We previously determined that osmotic agents and salicylic acid improved the cryopreservability of Vitis species (Volk et al., 2018). It has been reported that the addition of BA to the shooting medium has a positive effect on regrowth after $\mathrm{LN}$ exposure (Marković et al., 2014). In addition to BA, we included salicylic acid, glutathione (reduced form), and ascorbic acid to the pretreatment medium in an attempt to reduce the formation of reactive oxygen species during exposure to cryoprotectant and LN. The influence of cold acclimation pretreatment $\left(5{ }^{\circ} \mathrm{C}\right.$ for 2 weeks) before shoot tip desiccation was also assessed. Our results showed that the use of cold pretreatment did not significantly improve the regrowth of Vitis shoot tips after cryopreservation. For some species, cold acclimation pretreatments improved the regrowth and quality of regenerated plants after cryopreservation (Chang 
Table 3. Regrowth levels (\%) of shoot tips excised from nodal sections sourced from five Vitis species grown in vitro with 90 min of plant vitrification solution 2 (PVS2) exposure with and without liquid nitrogen (LN) exposure and without cold acclimation. ${ }^{\mathrm{z}}$

\begin{tabular}{llcc}
\hline & & $-\mathrm{LN}$ & $+\mathrm{LN}$ \\
\cline { 2 - 3 } Species & & \multicolumn{2}{c}{ PVS2 exposure time $(\mathrm{min})$} \\
\cline { 2 - 3 } V. actinifolia & Plant identifier & $73 \pm 3 \mathrm{a}$ & 90 \\
$V$. ficifolia & DVIT 2594.1 & $83 \pm 3 \mathrm{a}$ & $53 \pm 3 \mathrm{bc}$ \\
$V$. treleasi & DVIT 2008.1 & $83 \pm 8 \mathrm{a}$ & $43 \pm 3 \mathrm{c}$ \\
$V$ vinifera & DVIT 1410 & $88 \pm 3 \mathrm{a}$ & $68 \pm 3 \mathrm{ab}$ \\
Average & 'Riesling' & $83 \pm 3 \mathrm{a}$ & $58 \pm 3 \mathrm{ab}$ \\
\hline
\end{tabular}

${ }^{\mathrm{z}}$ Data represent mean \pm SE. Values followed by different letters within each column are significantly different at $P<0.05$ using Tukey's mean separation test.

Table 4. Regrowth level (\%) of shoot tips excised from nodal sections sourced from four Vitis species grown in vitro with 60,75, and 90 min of plant vitrification solution 2 (PVS2) exposure with and without liquid nitrogen (LN) exposure and without cold acclimation. ${ }^{z}$

\begin{tabular}{|c|c|c|c|c|}
\hline \multirow[b]{3}{*}{ Species } & \multirow[b]{3}{*}{ Plant identifier } & \multicolumn{3}{|c|}{$-\mathrm{LN}$} \\
\hline & & \multicolumn{3}{|c|}{ PVS2 exposure duration (min) } \\
\hline & & 60 & 75 & 90 \\
\hline V. actinifolia & DVIT 2594.1 & $75 \pm 10 \mathrm{a}$ & $70 \pm 10 \mathrm{a}$ & $65 \pm 10 a$ \\
\hline V. treleasi & DVIT 1410 & $57 \pm 4 \mathrm{a}$ & $47 \pm 7 \mathrm{a}$ & $44 \pm 4 \mathrm{a}$ \\
\hline$V$. vinifera & 'Riesling' & $83 \pm 3 a$ & $64 \pm 9 \mathrm{a}$ & $69 \pm 19 a$ \\
\hline$V . \times$ novae angeliae & DVIT 1457 & $83 \pm 7 \mathrm{a}$ & $82 \pm 7 \mathrm{a}$ & $78 \pm 2 \mathrm{a}$ \\
\hline \multirow[t]{3}{*}{ Average } & & $74 \pm 2$ & $65 \pm 1$ & $64 \pm 4$ \\
\hline & & \multicolumn{3}{|c|}{$+\mathrm{LN}$} \\
\hline & & \multicolumn{3}{|c|}{ PVS2 exposure duration (min) } \\
\hline Species & Plant identifier & 60 & 75 & 90 \\
\hline $\bar{V}$. actinifolia & DVIT 2594.1 & $73 \pm 13 \mathrm{a}$ & $62 \pm 18 \mathrm{a}$ & $58 \pm 2 a$ \\
\hline V. treleasi & DVIT 1410 & $34 \pm 1 \mathrm{a}$ & $32 \pm 2 \mathrm{a}$ & $40 \pm 0 \mathrm{a}$ \\
\hline$V$. vinifera & 'Riesling' & $50 \pm 6 \mathrm{a}$ & $54 \pm 6 \mathrm{a}$ & $35 \pm 5 \mathrm{a}$ \\
\hline$V . \times$ novae angeliae & DVIT 1457 & $58 \pm 3 a$ & $50 \pm 6 a$ & $59 \pm 7 \mathrm{a}$ \\
\hline Average & & $54 \pm 3$ & $49 \pm 4$ & $48 \pm 1$ \\
\hline
\end{tabular}

${ }^{\mathrm{z}}$ Data represent mean \pm SE. Values followed by different letters within the set of $-\mathrm{LN} / \mathrm{PVS} 2$ exposure combinations and within the set of $+\mathrm{LN} / \mathrm{PVS} 2$ exposure combinations are significantly different at $P<$ 0.05 using Tukey's mean separation test. These data were obtained by a second technical expert.

Table 5. Regrowth level (\%) of shoot tips excised from nodal sections sourced from four Vitis species grown in vitro with 60,75 , and 90 min of plant vitrification solution 2 (PVS2) exposure with and without liquid nitrogen (LN) exposure and 2 weeks of cold acclimation. ${ }^{\mathrm{z}}$

\begin{tabular}{|c|c|c|c|c|}
\hline \multirow[b]{3}{*}{ Species } & \multirow[b]{3}{*}{ Plant identifier } & \multicolumn{3}{|c|}{$-\mathrm{LN}$} \\
\hline & & \multicolumn{3}{|c|}{ PVS2 exposure duration (min) } \\
\hline & & 60 & 75 & 90 \\
\hline V. actinifolia & DVIT 2594.1 & $84 \pm 4 a$ & $80 \pm 13 a$ & $76 \pm 11 a$ \\
\hline$V$. ficifolia & DVIT 2008.1 & $54 \pm 19 a$ & $58 \pm 8 \mathrm{a}$ & $73 \pm 8$ a \\
\hline V. treleasii & DVIT 1410 & $90 \pm 0 \mathrm{a}$ & $73 \pm 8 \mathrm{a}$ & $72 \pm 2 \mathrm{a}$ \\
\hline$V$. vinifera & 'Riesling' & $76 \pm 9 \mathrm{a}$ & $77 \pm 4 \mathrm{a}$ & $65 \pm 15 \mathrm{a}$ \\
\hline \multirow[t]{3}{*}{ Average } & & $76 \pm 4$ & $72 \pm 2$ & $71 \pm 3$ \\
\hline & & \multicolumn{3}{|c|}{$+\mathrm{LN}$} \\
\hline & & \multicolumn{3}{|c|}{ PVS2 exposure duration (min) } \\
\hline Species & Plant Identifier & 60 & 75 & 90 \\
\hline V. actinifolia & DVIT 2594.1 & $54 \pm 7 \mathrm{ab}$ & $85 \pm 0 \mathrm{a}$ & $70 \pm 5 \mathrm{ab}$ \\
\hline$V$. ficifolia & DVIT 2008.1 & $45 \pm 5 b$ & $38 \pm 13 b$ & $47 \pm 3 b$ \\
\hline V. treleasii & DVIT 1410 & $42 \pm 7 b$ & $43 \pm 13 b$ & $43 \pm 3 b$ \\
\hline$V$. vinifera & 'Riesling' & $63 \pm 3 \mathrm{ab}$ & $73 \pm 3 \mathrm{ab}$ & $68 \pm 3 \mathrm{ab}$ \\
\hline Average & & $51 \pm 1$ & $60 \pm 3$ & $57 \pm 1$ \\
\hline
\end{tabular}

${ }_{\mathrm{z}}$ Data represent mean \pm SE. Values followed by different letters within the set of $-\mathrm{LN} / \mathrm{PVS} 2$ exposure combinations and within the set of $+\mathrm{LN} / \mathrm{PVS} 2$ exposure combinations are significantly different at $P<$ 0.05 using Tukey's mean separation test. These data were obtained by a second technical expert.

and Reed, 2000; Kushnarenko et al., 2009; Mathew et al., 2018; Panta et al., 2015) and may be helpful for the cryoprocessing of some untested Vitis species and/or cultivars.

We investigated whether the described droplet vitrification procedure could be per- formed by another technician in the laboratory. We obtained similar regrowth levels for the cryopreserved shoot tips across all the evaluated accessions when the experiments were performed by two technicians skilled in tissue culture and cryopreservation proce- dures. The reproducibility of results across technicians helped to demonstrate that the described procedures can be replicated, thus increasing the likelihood of success for genebanks that may adopt this method for Vitis cryopreservation.

In addition to the shoot tip cryopreservation method described herein, Vitis also could be cryopreserved as seeds or pollen collected from the wild or by performing controlled crosses among accessions in the vineyard (Bi et al., 2017; Ganeshan, 1985; Volk et al., 2005, 2017). Vitis is genetically heterozygous; therefore, there will be some instances when clonal preservation will be needed, specifically for hybrids, single accessions of a species, and specific genotypes of interest. In these cases, shoot tip preservation is preferred over seeds or pollen ( $\mathrm{Bi}$ et al., 2017).

\section{Conclusions}

Our droplet vitrification cryopreservation technique resulted in high regrowth levels of cryopreserved Vitis species using shoot tips derived from in vitro stock plants. The high regrowth levels that we obtained for cryopreserved shoot tips could be independently replicated by two technicians skilled in tissue culture and cryopreservation procedures, thus suggesting that this method may be ready for implementation in Vitis genebank collections.

\section{Literature Cited}

Benelli, C., A.D. Carlo, and F. Engelmann. 2013. Recent advances in the cryopreservation of shoot-derived germplasm of economically important fruit trees of Actinidia, Diospyros, Malus, Olea, Prunus, Pyrus and Vitis. Biotechnol. Adv. 31:175-185.

Benelli, C., M. Lambardi, and A. Fabbri. 2003. Low temperature storage and cryopreservation of the grape rootstock "Kober 5BB". Acta Hort. 623:249-253.

Benson, E.E. and K. Harding. 2012. Cryopreservation of shoot tips and meristems: An overview of contemporary methodologies. Methods Mol. Biol. 877:191-226.

Benson, E.E. 2008. Cryopreservation of phytodiversity: A critical appraisal of theory \& practice. Crit. Rev. Plant Sci. 27:141-219.

Bettoni, J.C., R. Bonnart, A.N. Shepherd, A.A Kretzschmar, and G.M. Volk. 2019a. Successful cryopreservation of Vitis vinifera 'Chardonnay' from both in vitro and growth chamber source plants. Acta Hort. 1234:211218

Bettoni, J.C., R. Bonnart, A.N. Shepherd, A.A Kretzschmar, and G.M. Volk. 2019b. Modifications to a Vitis shoot tip cryopreservation procedure: Effect of shoot tip size and use of cryoplates. Cryo Lett. (In Press).

Bi, W.L., C. Pan, X.Y. Hao, Z.H. Cui, M.M. Kher, Z. Markovic, Q.W. Wang, and J.A. Teixeira da Silva. 2017. Cryopreservation of grapevine (Vitis spp.) - a review. In Vitro Cell. Dev. Biol. Plant 53:449-460.

Bi, W.L., X.Y. Hao, Z.H. Cui, G.M. Volk, and Q.C. Wang. 2018a. Droplet-vitrification cryopreservation of in vitro-grown shoot tips of grapevine (Vitis spp.). In Vitro Cell. Dev. Biol. Plant 54:590-599. 
Bi, W.L., X.Y. Hao, Z.H. Cui, R. Pathirana, G.M. Volk, and Q.C. Wang. 2018b. Shoot tip cryotherapy for efficient eradication of grapevine leafroll-associated virus-3 from diseased grapevine in vitro plants. Ann. Appl. Biol. 173:261-270.

Carimi, F., R. Pathirana, and A. Carra. 2011. Biotechnologies for germplasm management and improvement, p. 199-249. In: P.V. Szabo and J. Shojania (eds.). Grapevines - Varieties, Cultivation and Management. Nova Science Publishers, New York, NY.

Carimi, F., A. Carra, B. Panis, and R. Pathirana. 2016. Strategies for conservation of endangered wild grapevine (Vitis vinifera $\mathrm{L}$. subsp. sylvestris (C.C. Gmel.) Hegi). Acta Hort. 1115:81-86

Chang, Y. and B.M. Reed. 2000. Extended alternating-temperature cold acclimation and culture duration improve pear shoot cryopreservation. Cryobiology 40:311-322.

Eibach, R., E. Zyprian, L. Welter, and R. Töpfer. 2007. The use of molecular markers for pyramiding resistance genes in grapevine breeding. Vitis $46: 120-124$.

Esensee, V. and C. Stushnoff. 1990. Cryoconservation of dormant grape (Vitis sp.) buds. HortScience 25:90.

Ganeshan, S. 1985. Cryogenic preservation of grape, Vitis vinifera L., pollen. Vitis 173:169173.

Ganino, G., A. Silvanini, D. Beghé, C. Benelli, M. Lambardi, and A. Fabbri. 2012. Anatomy and osmotic potential of Vitis rootstock shoot tips recalcitrant to cryopreservation. Biol. Plant. $56: 78-82$.

Hassan, N.A. and A.M. Haggag. 2013. Cryopreservation of two Egyptian grape (Vitis vinifera). Cultivars Using Two Steps Vitrification Protocol. World Appl. Sci. J. 28:254-258.

Hassan, N.A., A.H. Gomaa, M.A. Shahin, and A.A. El Homosany. 2013. In vitro storage and cryopreservation of some grape varieties. J. Hort. Sci. Ornam. Plants 5:183-193.

Kaya, E., A. Alves, L. Rodrigues, M. Jenderek, M. Hernandez-Ellis, A. Ozudogru, and D. Ellis. 2013. Cryopreservation of Eucalyptus genetic resources. Cryo Lett. 34(6):608-618.

Kaya, E. and F.V.D. Souza. 2017. Comparison of two PVS2-based procedures for cryopreservation of commercial sugarcane (Saccharum spp.) germplasm and confirmation of genetic stability after cryopreservation using ISSR markers. In Vitro Cell. Dev. Biol. Plant 53:410 417.

Kushnarenko, S.V., N.V. Romadanova, and B.M. Reed. 2009. Cold acclimation improves regrowth of cryopreserved apple shoot tips. Cryo Lett. 30:47-54.

Li, B., J. Jiang, X. Fan, Y. Zhang, H. Sun, G. Zhang, and C. Liu. 2017. Molecular Characterization of Chinese Grape Landraces (Vitis L.) Using Microsatellite DNA Markers. HortScience 52:533-540.

Mandal, B.B. and S. Dixit-Sharma. 2007. Cryopreservation of in vitro shoot tips of Dioscorea deltoidea Wall., an endangered medicinal plant: Effect of cryogenic procedure and storage duration. Cryo Lett. 28:461-470.

Marković, Z., P. Chatelet, D. Preiner, I. Sylvestre, J.K. Kontić, and F. Engelmann. 2014. Effect of shooting medium and source of material on grapevine (Vitis vinifera L.) shoot tip recovery after cryopreservation. Cryo Lett. 35:40-47.

Marković, Z., P. Chatelet, A. Peyrière, D. Preiner, I. Engelmann-Sylvestre, J. Karoglan, and F. Engelmann. 2013a. Effect of proline pretreatment on grapevine shoot-tip response to a droplet-vitrification protocol. Amer. J. Plant Sci. 4:2414-2417.

Marković, Z., P. Chatelet, I. Sylvestre, J.K. Kontic, and F. Engelmann. 2013b. Cryopreservation of grapevine (Vitis vinifera $\mathrm{L}$.) in vitro shoot tips. Cent. Eur. J. Biol. 8:993-1000.

Mathew, L., A. McLachlan, R. Jibran, D.J. Burritt, and R. Pathirana. 2018. Cold, antioxidant and osmotic pre-treatments maintain the structural integrity of meristematic cells and improve plant regeneration in cryopreserved kiwifruit shoot tips. Protoplasma 255:1-13.

Matsumoto, T. and A. Sakai. 2003. Cryopreservation of axillary shoot tips of in vitro-grown grape (Vitis) by a two-step vitrification protocol. Euphytica 131:299-304.

Murashige, T. and F. Skoog. 1962. A revised medium for rapid growth and bioassays with tobacco tissue cultures. Physiol. Plant. 15:473-497.

OIV (International Organisation of Vine and WineIntergovernmental Organisation). 2018. World Viticulture Situation; OIV Statistical Report on World Vitiviniculture. <http://www.oiv.int/ public/medias/6371/oiv-statistical-report-on-worldvitiviniculture-2018.pdf>.

Panta, A., B. Panis, C. Ynouye, R. Swennen, W. Roca, D. Tay, and D. Ellis. 2015. Improved cryopreservation method for the long-term conservation of the world potato germplasm collection. Plant Cell Tissue Organ Cult. 120: $117-125$.

Pathirana, R., A. McLachlan, D. Hedderley, B. Panis, and F. Carimi. 2016. Pretreatment with salicylic acid improves plant regeneration after cryopreservation of grapevine (Vitis spp.) by droplet vitrification. Acta Physiol. Plant. 38:1-11.

Pathirana, R., A. Mclachlan, D. Hedderley, A. Carra, F. Carimi, and B. Panis. 2015. Removal of leafroll viruses from infected grapevine plants by droplet vitrification. Acta Hort. 1083:491-498.

Plessis, P.C., C. Leddet, and J. Dereuddre. 1993. Cryopreservation of Vitis vinifera L. cv. Chardonnay shoot tips by encapsulationdehydration: Effects of pre-treatment, cooling and post culture conditions. Cryo Lett. 14:309320.

Postman, J., K. Hummer, E. Stover, R. Krueger, P. Forsline, L.J. Grauke, F. Zee, T. Ayala-Silva, and B. Irish. 2006. Fruit and nut genebanks in the U.S. National Plant Germplasm System. HortScience 41:1188-1194.

Reed, B.M. 2014. Antioxidants and cryopreservation, the new normal? Acta Hort. 1039:41-48.

Sakai, A., S. Kobayashi, and I. Oiyama. 1990. Cryopreservation of nucellar cells of navel orange (Citrus sinensis Osb. var. brasiliensis Tanaka) by vitrification. Plant Cell Rep. 9: 30-33.

Smith, B.P., N.B. Morales, M.R. Thomas, H.M. Smith, and P.R. Clingeleffer. 2017. Grapevine rootstocks resistant to the root-knot nematode Meloidogyne javanica. Austral. J. Grape Wine Res. 23:125-131.
Souza, F.V.D., E. Kaya, L.J. Vieira, E.H. Souza, V.B. Amorim, D. Skogerboe, T. Matsumoto, A.A.C. Alves, C.A.S. Ledo, and M.M. Jenderek. 2016. Droplet-vitrification and morphohistological studies of cryopreserved shoot tips of cultivated and wild pineapple genotypes. Plant Cell Tissue Organ Cult. 124:351-360.

Towill, L.E., P.L. Forsline, C. Walters, J.W. Waddell, and J. Laufmann. 2004. Cryopreservation of Malus germplasm using a winter vegetative bud method: Results from 1915 accessions. Cryo Lett. 25:323-334.

Volk, G.M., C.M. Richards, A.A. Reilley, and A.D. Henk. 2005. Ex situ conservation of vegetatively propagated species: Development of a seed-based core collection for Malus sieversii. J. Amer. Soc. Hort. Sci. 130:203-210.

Volk, G.M., A.D. Henk, P.L. Forsline, A.K. SzewcMcFadden, G. Fazio, H. Aldwinckle, and C.M. Richards. 2017. Seeds capture the diversity of genetic resource collections of Malus sieversii maintained in an orchard. Genet. Resources Crop Evol. 64:1513-1528.

Volk, G.M., A.D. Henk, M. Jenderek, and C.M. Richards. 2016. Probabilistic viability calculations for cryopreserving vegetatively propagated collections in genebanks. Genet. Resources Crop Evol. 64:1613-1622.

Volk, G.M., A. Shepherd, and R.M. Bonnart. 2018. Successful cryopreservation of Vitis shoot tips: Novel pretreatment combinations applied to nine species. Cryo Lett. 39:322-330.

Wang, M.R., L. Chen, J.A.T. Silva, G.M. Volk, and Q.C. Wang. 2018. Cryobiotechnology of apple (Malus spp.): Development, progress and future prospects. Plant Cell Rep. 37:1-21.

Wang, B., R.R. Wang, Z.H. Cui, W.L. Bi, J.W. Li, B.Q. Li, E.A. Ozudogru, G.M. Volk, and Q.C. Wang. 2014. Potential applications of cryogenic technologies to plant genetic improvement and pathogen eradication. Biotechnol. Adv. 32:583-595.

Wang, Q.C., M. Mawassi, P. Li, R. Gafny, I. Sela, and E. Tanne. 2003a. Elimination of grapevine virus A (GVA) by cryopreservation of in vitrogrown shoot tips of Vitis vinifera L. Plant Sci. 165:321-327.

Wang, Q.C., P. Li, Ö. Batuman, R. Gafny, and M. Mawassi. 2003b. Effect of benzyladenine on recovery of cryopreserved shoot tips of grapevine and citrus cultured in vitro. Cryo Lett. 24:293-302.

Wang, Q.C., E. Tanne, A. Arav, and R. Gafny. 2000. Cryopreservation of in vitro-grown shoot tips of grapevine by encapsulationdehydration. Plant Cell Tissue Organ Cult. 63:41-46.

Yi, J.-Y., K. Balaraju, H.-J. Baek, M.-S. Yoon, H.-H. Kim, and Y.-Y. Lee. 2018. Cryopreservation of Citrus limon (L.) Burm. F shoot tips using a droplet-vitrification method. Korean J. Plant Res. 31:684-694.

Zhai, Z., Y. Wu, F. Engelmann, R. Chen, and Y. Zhao. 2003. Genetic stability assessments of plantlets regenerated from cryopreserved in vitro cultured grape and kiwi shoot-tips using RAPD. Cryo Lett. 24:315-322.

Zhao, C., Y. Wu, F. Engelmann, and M. Zhou. 2001. Cryopreservation of axillary buds of grape (Vitis vinifera) in vitro plantlets. Cryo Lett. 22:321-323. 